\title{
PENGARUH PEMAHAMAN AGAMA, MOTIFASI MENDAPATKAN PROFIT DAN TINGKAT PENDIDIKAAN TERHADAP KESADARAN SERTIFIKASI HALAL BAGI PRODUSEN MAKANAN DI KABUPATEN SLEMAN DAN BANTUL
}

\author{
Waluyo \\ Dosen Institut Agama Islam Negeri ( IAIN) Surakarta \\ wluyo@yaboo.co.id
}

\begin{abstract}
This research aims to determine whether there is an understanding of the influence of religion, profit motivation and education levels of the awareness of certified halal food for producers in Sleman and Bantul, as well as to find among the independent variables which are more significant. This research is a quantitative study with multiple regression analysis.

Independent variables (religious understanding, motivation and profit levels) simultaneously have significant effect on awareness of halal certification for food producers in Sleman and Bantul with the amount of influence of $66.7 \%$. The independent variables that have a significant effect on the dependent variable (motivation of certified halal) is understanding of religion variable and profit motivation.
\end{abstract}

Keywords: Awareness of Certified Halal, Religious Understanding, Profit Motivation and Education Levels.

\begin{abstract}
Abstrak
Peneltian ini bertujuan untuk mengetahui apakah ada pengarub pemahaman agama, motivasi mendapatkan profit serta tingkat pendidikan terhadap kesadaran bersertifikasi halal bagi para produsen makanan di Sleman dan Bantul, serta untuk mengetahui diantara variabel-variabel independen tersebut manakah yang lebih berpengarub secara signifikan. Penelitian ini adalab penelitian kuantitatif dengan analisis regresi berganda.

Variabel-variabel independen (pemahaman agama, motifasi mendapatkan profit dan tingkat pendidikan) secara simultan berpengarub signifikan terhadap kesadaran sertifikasi halal bagi produsen makanan di Sleman dan Bantul dengan besaran pengarub 66, 7\%. Adapun variabel independen yang mempunyai pengarub signifikan terhadap variabel dependen (motifasi bersertifikasi halal) adalah variabel pemahaman agama dan motifasi mendapatkan profit.
\end{abstract}

Kata kunci: Kesadaran Bersertifikasi Halal, Pemahaman Agama, Motifasi Mendapatkan Profit dan Tingkat Pendidikan. 


\section{Pendahuluan}

Halal dan haram dalam ajaran Islam merupakan persoalan yang sangat urgen dan dipandang sebagai inti keberagamaan, karena keduanya sebagai ukuran paten bagi seorang muslim untuk melakukan atau menggunakan sesuatu. Kesalahan dalam memahami persoalan halal dan haram dapat menyebabkan penyimpangan dan ekstrimisme, baik ekstrim kanan maupun ekstrim kiri. Ekstrimisme kanan seperti terfomulasikan dalam kalangan kaum Brahmana Hindu beraliran keras, Rahib-Rahib Kristen yang bertindak sewenang-wenang dan aliran lain yang berprinsip menyiksa diri dan mengaharamkan rezeki yang baik-baik serta perhiasan yang telah dihalalkan oleh Allah untuk hamba-hamba-Nya. Sedangkan ekstrimisme kiri adalah seperti tercermin pada aliran "mazdak" yang lahir di Persi (Qardhawi, 1985: 18). Hal ini juga terjadi pada bangsa Arab jahiliyah, mereka mengharamkan hal-hal yang baik dari tanaman dan binatang, kemudian menjadikan semua ini sebagai hukum agama. Ekstrimisme ini telah dikisahkan di dalam beberapa ayat al-Qur'an, di antaranya adalah surat al-An'am ayat 137-138. Syeikh as-Sa'di (2005: 274-275) dalam kitabnya Taisirul Karimir Rabman Fi Tafsiri Kalamil Manan menjelaskan bahwa ekstrimisme bangsa Arab Jahiliyah ini disebabkan oleh beberapa hal, seperti rusaknya akal pikiran, sempitnya pengalaman, dan kebodohan yang akut.

Selain di Arab, ekstrimisme juga terjadi di Barat. Dunia barat kini tengah menghadapi problem homoseksual yang sangat serius. Padahal kalau kita lihat sejarah, pada jaman dahulu dunia barat memperlakukan kaum homoseks dengan sangat kejam dan sadis. Robert Held dalam bukunya Inquissition, sebagaimana dikutip oleh Husaini (2005: 36), memuat foto-foto dan lukisan yang sangat mengerikan tentang kejahatan Inquisisi yang dilakukan tokoh-tokoh gereja saat itu.

Seiring dengan berjalannya arus globalisasi muncul homogenisasi food (makanan), fun (hiburan), fashion (mode) dan thought (pemikiran). Hal ini dapat menihilkan kehati-hatian (ibtiyath) akan esensi produk yang dikonsumsi, baik dari segi asal usul, komposisi (ingrendiens) dan status hukum yang terkandung di dalamnya 
(Muhamad dan Pelu, 2009: 1).

Islam telah mengatur cara pemenuhan kebutuhan manusia sesuai dengan tuntutan garis-garis maqashid asy syari'ab (tujuan syariat Islam) (As Syatibi, tt: 12) yang sarat akan nilai, akan tetapi madzhab ekonomi modern yang lebih condong kepada aliran kapitalis memunculkan mitos masyarakat modern yang mengamini bahwa ekonomi dan bisnis adalah kegiatan yang harus dijauhkan dari nilai etika atau moral. Muhammad dan Pelu (2009: 3) dalam bukunya Label Halal memaparkan pendapat Friedman yang secara eksplisit menandaskan bahwa keberadaan organisasi bisnis tidak lain adalah untuk memenuhi dan mencapai kepentingan pemilik dan pemegang saham. Pendapat Friedman tersebut jelas merupakan refleksi dari filsafat materialisme yang menurut Chapra (2001: 49) tidak akan mampu mewujudkan tujuan sosial bahkan akan bisa mengalami kebangkrutan.

Stiglitz (2006: xiii) dalam bukunya Dekade Keserakahan Era '90-an dan Awal Mula Petaka Ekonomi Dunia mengungkapkan bahwa etika yang terabaikan menjadi salah satu faktor ambruknya perusahaan-perusahaan di Amerika dan Eropa, seperti ambruknya perusahaan raksasa "World Com" dan "Enron". Sementara Apriyantono dan Nurbowo (2003: 11-13), dalam hal ini memberikan contoh kasus lokal yaitu haramnya penyedap rasa Ajinomoto, restoran fast food "Hong Bin Lou Halal".

Berdasarkan fakta-fakta di atas, akhirnya muncul gerakan bisnis yang mencoba menempatkan nilai-nilai etika dan agama sebagai salah satu instrumen di dalamnya. Salah satu aspek terpenting yang menandai bangkitnya etika bisnis di kalangan perusahaan (produsen) adalah munculnya produk-produk bisnis yang bersertifikasi halal, baik yang berskala internasional seperti Codek, Islamic Food and Nutrition Council of America" (IFANCA) di Amerika, Australia Quarantine and Inspection Service" (AQIS) di Australia, maupun yang berskala nasional yaitu lembaga pengkajian pangan, obat dan makanan (LPPOM) MUI (Sakr, 1996: 21 dan Jurnal Halal MUI, No.79 Sepetember-Oktober 2009: 26).

Meskipun regulasi yang mengatur produk pangan ini telah dikeluarkan oleh LPPOM MUI, namun tidak semua produsen 
memberikan respon yang sama. Gabungan pengusaha makanan dan minuman (GAPMMI) dalam surveinya mengungkap bahwa dari jutaan produk sampai kini yang besertifikat halal baru sekitar 2000-an item. Hal ini berarti produk-produk yang disertifikasi dari sudut kehalalannya - baru mencapai 10\% saja dari ribuan perusahaan (Apriyanto dan Nurbowo, 2003: 4-5). Sementara dilain pihak penelitian "Indohalal.Com", Yayasan "Halalan Thoyyibah" dan LPPOM MUI akhir 2002 menunjukkan 77,8 \% responden menjadikan jaminan kehalalan sebagai pertimbangan pertama dalam berbelanja produk makanan, minuman, kosmetik dan resto. Sebanyak 93,9 \% responden menyetujui apabila produk mencantumkan label dan nomor sertifikat halal. Hasil survei Frontier pada tahun 2001 menunjukkan sebanyak 57,9\% konsumen selalu memperhatikan label halal. $86 \%$ responden menghendaki wajibnya produsen mencantumkan label halal dan sebanyak 83 $\%$ responden mengaharapkan ada sanksi yang tegas bagi pelaku bisnis yang melanggar peraturan (Apriyanto dan Nurbowo, 2003: 4 dan Apriyantono, 2004: 11).

Berangkat dari fenomena di atas, timbul keinginan penyusun untuk meneliti lebih lanjut tentang sertifikasi halal. Pada penelitian ini penulis tidak meneliti tingkat preferensi konsumen terhadap produk halal akan tetapi mencoba menggali hal-hal yang mempengaruhi kesadaran produsen makanan untuk sertifikasi halal. Penelitian ini dilakukan di Yogyakarta khususnya di kabupaten Sleman dan Bantul. Dari penelitian ini diharapkan dapat memberikan masukan kepada LPPOM MUI dalam melakukan pembinaan para produsen agar turut serta mensukseskan program sertifikasi halal yang sudah sangat mendesak untuk dilakukan oleh mereka guna melindungi konsumen dari produk yang membahayakan.

Berdasarkan latar belakang masalah, dirumuskan permasalahan sebagai berikut: apakah ada pengaruh pemahaman agama, motivasi mendapatkan profit serta tingkat pendidikan terhadap kesadaran para produsen makanan di Sleman dan Bantul dalam menerapkan sertifikasi halal terhadap produk mereka? diantara variabelvariabel independen tersebut manakah yang lebih berpengaruh secara signifikan dan manakah yang tidak berpengaruh terhadap kesadaran sertifikasi halal di kabupaten Sleman dan Bantul? 


\section{Teori Sertifikasi Halal}

Majelis Ulama Indonesia (MUI) menetapkan produk halal adalah produk yang memenuhi syarat kehalalan sesuai dengan syari'at Islam, dengan rincian tidak mengandung bahan yang bersumber dari babi, bahan-bahan yang berasal dari organ manusia, darah, kotoran dan lain sebagainya. Bahkan yang berasal dari hewan halal tetapi disembelih tidak sesuai dengan tata cara syari'at agama Islam. Selain itu, juga semua makanan dan minuman yang tidak mengandung khamar (Pedoman Fatwa Produk Halal, 2003: 2). Adapun kehalalan itu memiliki batasan-batasan, antara lain: (1) halal secara substansi (dzatihi), (2) halal dari segi sifat, (3) halal dari segi tempat, (4) halal dari segi proses, (5) halal instrument pemrosesannya, (6) halal dalam penyimpanannya, (7) halal dalam distribusinya, dan (8) halal dalam penyajiannya.

Dalam buku Pedoman Fatwa Produk Halal (2003: 53) disebutkan bahwa sertifikat halal adalah fatwa tertulis Majlis Ulama Indonesia yang menyatakan kehalalan suatu produk berdasarkan syari'at Islam. Sertifikasi halal juga merupakan syarat dalam pencantuman label halal pada kemasan produk. Adapun tujuan pelaksanaan sertifikat pada produk pangan adalah untuk melindungi konsumen muslim terhadap produk pangan yang tidak menjamin keamanan (keracunan, gangguan kesehatan) maupun batin (kehalalan produk), mengingat di Indonesia pada saat sekarang ini telah banyak beredar produk pangan baik buatan dalam negeri maupun yang didatangkan dari negara lain yang sangat diragukan kehalalannya.

Sertifikasi halal bagi produsen merupakan sebuah konsep yang memiliki makna tanggung jawab. Tanggung jawab ini merujuk pada kesadaran industri sebagai entitas yang tidak dapat dipisahkan dari lingkungan sosial sekaligus tanggung jawab pemilik industri secara personal terhadap kepentingan orang lain (kemaslahatan konsumen). Maka inilah yang kemudian kita sebut dengan arti Humanisme, yaitu salah satu paham yang episentrum gerakannya pada kemaslahatan manusia, yang dikenal dalam kaidah ushul fiqih dengan istilah al-Masholih al-Mursalah yang terfokus pada dua titik terpenting yaitu menghindarkan 
kehidupan dari kehancuran dan mengantarkannya kepada tercapainya maksud-maksud baik yang sifatnya mengikuti tujuan yang inti yaitu terwujudnya keadilan dalam kehidupan (an-Najar, 2002: 21).

Perbuatan-perbuatan yang mengandung unsur kedholiman yang merupakan lawan dari keadilan dalam dunia bisnis telah diuraikan dengan panjang lebar dalam kitab-kitab fiqih klasik maupun kontemporer. Unsur-unsur yang mengandung kedholiman bisnis seperti intimidasi, pemalsuan, ghabn (penipuan harga barang), riba dan yang lainnya (Ibnu Rusyd, tth: 93 dan Sabiq, 1999: 76).

Terkait dengan sertifikasi halal, beberapa kalangan telah melakukan penelitian terutama yang terkait dengan preferensi konsumen terhadap produk pangan halal. Pertama, Aitelmaelem, dkk, (2005: 13) telah melakukan penelitian di Kanada dengan jumlah penduduk muslim sebanyak 600.000 jiwa. Dalam penelitian tersebut menggunakan sampel 600 konsumen muslim dan diketahui bahwa 88\% responden menganggap sangat penting mengkonsumsi daging halal, $72 \%$ responden menyatakan bahwa mereka hanya akan mengkonsumsi makanan yang status kehalalannya benar-benar sudah jelas, serta $71 \%$ responden menempatkan makanan yang halal pada posisi pertama. Kedua, Penelitian di Malaysia yang dilakukan oleh Muhammad, dkk, (2009: 51) terhadap 525 responden. Dari hasil penelitian tersebut dapat diketahui sebanyak 57\% (299 orang) menyatakan bahwa produk halal tersebut sangat penting, 30\% (158 orang) menyatakan bahwa produk halal tidak penting, dan $13 \%$ (68 orang) menyatakan tidak mngetahui. Sementara Abdul, dkk, (2009: 45) pernah melakukan penelitian untuk mengetahui sejauh mana perhatian konsumen terhadap sertifikat dan label halal serta kandungan makanan. Penelitian ini ditujukan kepada responden yang Muslim dan juga non-Muslim di Malaysia. Hasil penelitian menyatakan bahwa sebanyak 95\% dari responden memperhatikan label halal dan kandungan makanan yang dibeli sewaktu mereka berbelanja. 


\section{Teori Kesadaran}

Kesadaran adalah tahu, mengerti, paham serta berperilaku sesuai dengan hukum tertentu (Poerwadarminta, 1949: 106). Widjaja (1980: 14) mengatakan bahwa sadar dapat diartikan dengan merasa tahu, ingat dengan keadaan yang sebenarnya atau ingat akan dirinya sendiri. Sementara Iqbal (2008: 56) mendifinisikan kesadaran sebagai keragaman prinsip yang murni spiritual, suatu cara khusus dari tata laku yang mempunyai perbedaan esensial dengan tata laku mesin yang dijalankan dari luar. Menurutnya, kesadaran berfungsi memberikan suatu penyinaran gerak hidup manusia seterusnya sebagai suatu keadaan self-konsentrasi.

Dari definisi kesadaran menurut para tokoh di atas juga terlihat bahwa kesadaran itu muncul tidak dengan sendirinya, akan tetapi ada faktor yang melatarbelakngi. Bagi Poerwadarminto kesadaran seseorang tentu berasal dari pengetahuan hukum yang berlaku, sementara menurut Widjaja kesadaran seseorang muncul karena dia memahami hakekat dirinya sendiri dan pada pandangan Iqbal kesadaran tumbuh karena pemahaman religius seseorang.

Kesadaran versi Iqbal dapat dieksplorasi dengan beberapa ayat dalam Al-Qur'an, diantaranya adalah surat al-Hasyr ayat 19:

"Dan janganlah kamu seperti orang-orang yang lupa kepada Allah, lalu Allah menjadikan mereka lupa kepada mereka sendiri. mereka Itulah orang-orang yang fasik."

Asy-Syaukani (2001: 1731) berpandangan bahwa ayat ini mengharuskan manusia untuk menjahui sifat-sifat orang-orang yang melupakan Allah yaitu melanggar perintah-Nya serta tidak takut terhadap-Nya. Allah akan menjadikan orang seperti ini lupa diri dengan terus menerus melakukan kemaksiatan dan kemungkaran.

Berpijak dengan ayat di atas, maka hakekat kesadaran dalam Islam adalah mengenal Allah dan selalu mengingat-Nya serta sadar akan kedudukan dirinya sebagai hamba Allah dan juga khalifah di muka bumi sehingga tidak terjerumus untuk berbuat kefasikan (melanggar larangan Tuhan) yang diwujudkan dengan melaksanakan perintah-Nya dan menjauhi larangan-Nya sebagai wujud penghambaan terhadap-Nya dan juga harus diringi oleh aksi 
sosialnya dalam rangka mewujudkan masyarakat yang aman dan tentram, salah satunya adalah dengan sertifikasi halal.

Terkait dengan kesadaran sertifikasi halal, telah dilakukan beberapa penelitian diantaranya yang dilakukan oleh Gabungan Pengusaha Makanan dan Minuman (GAPMMI) yang mengungkap temuan bahwa kebutuhan konsumen yang mayoritas muslim di tanah air terhadap produk pangan halal tidak diimbangi dengan kepedulian produsen. Minimnya item produk yang bersetifikat halal sebagai indikatornya. Dari ribuan bahkan jutaan produk sampai kini yang besertifikat halal baru sekitar 2000-an item. Hal ini berarti produk-produk yang disertifikasi - dari sudut kehalalannya - baru mencapai 10\% saja dari ribuan perusahaan (Apriyanto dan Nurbowo, 2003: 4-5)

\section{Teori Pemahaman Agama}

Pemahaman adalah tingkatan kemampuan yang mengharapkan seseorang mampu memahami arti atau konsep, situasi serta fakta yang diketahuinya. Dalam hal ini ia tidak hanya hapal secara verbalitas, tetapi memahami konsep dari masalah atau fakta yang ditanyakan, maka operasionalnya dapat membedakan, mengubah, mempersiapkan, menyajikan, mengatur, menginterpretasikan, menjelaskan, mendemonstrasikan, memberi contoh, memperkirakan, menentukan, dan mengambil keputusan (Purwanto, 1997: 44). Menurut Azwar (1987: 62), dengan memahami berarti sanggup menjelaskan, mengklasifikasikan, mengikhtisarkan, meramalkan, dan membedakan.

Indikator-indikator pemahaman menurut para pakar di atas kalau kita tarik dan diterapkan pada konsep pemahaman agama akan didapatkan kesimpulan bahwa orang yang paham terhadap agama adalah orang yang dapat memperkirakan, menentukan, memperluas, menyimpulkan, menganalisis, memberi contoh, menuliskan kembali, mengklasifikasikan, dan mengikhtisarkan konsep agamanya. Dalam kitab-kitab ushul fiqih, orang yang memilki indikator semacam itu disebut mujtahid bukan masyarakat awam (Al-Utsaimin, 2003: 130). 
Para ulama' telah memberikan batasan-batasan tertentu bagi masyarakat awam dalam memahami agama Islam. Masyarakat diwajibkan - fardhu 'ain - memahami agama dalam masalah-masalah pokok yaitu masalah agama yang dianggap tidak dapat tegak kecuali dengan memahaminya sebagaimana yang dikatakan oleh Syeik Wahab (1997: 20) dalam kitab Utsulu ats-Tsalatsah. Masalah-masalah yang harus dipahami tersebut seperti yang dikatakan oleh Syeik Nashir bin Sulaiman al-Umar, yaitu meliputi rukun iman, rukun Islam dan amalan-amalan wajib bagi setiap orang (www.almoslim.net). Sementara indikator pemahaman yang dikehendaki oleh Islam dari masyarakat awam dalam memahami persolan-persolan tersebut adalah pemahaman global yang tidak sampai menyentuh tataran ijtihad karena memahami agama dengan sangat mendalam hukumnya sunnah (al-Utsaimin, 1997: 21). Pemahaman global terhadap agama meliputi pengetahuan terhadap hukum-hukum yang berkenaan dengan rukun iman dan rukun Islam serta amalan-amalan yang harus dikerjakan setiap hari termasuk tata cara berbisnis dan juga bermuamalah dengan orang lain.

\section{Teori Profit Oriented}

Bisnis selalu berorientasi pada pencapaian keuntungan (profit oriented) dengan perantara buying and seling of goods dengan modal pokok yang minim guna mendapat keuntungan yang melebihi modal pokok adalah merupakan watak dasar bisnis.

Menurut Alma (2009: 30) untuk mendapatkan profit yang tinggi para produsen berusaha untuk menjawab tiga tantangan besar yaitu tantangan produktifitas, tantangan kualitas dan tantangan pasar. Kotler (1989: 30), menjelaskan bahwa untuk meningkatkan laba maka perusahaan harus memperjelas misi perusahaan dengan memperbaiki dan meningkatkan pelayanan kepada pelanggan, dan juga perlu mengatur pemasarannya agar tepat sasaran.

Berdasarkan teori yang dikembangkan oleh Alma dan Kotler tersebut, maka sertifikasi halal disamping merefleksikan visi teologis yang selama ini tercerabut akarnya dari kegiatan bisnis juga merupakan instrumen strategis yang mempunyai nilai tinggi bagi produsen untuk mendapatkan laba terutama di negara-negara yang penduduknya mayoritas Muslim. 


\section{Teori Tingkat Pendidikan}

Pendidikan menurut Undang-Undang No. 20 tahun 2003 pasal 1 ayat (1) menyatakan bahwa "Pendidkan adalah usaha sadar dan terencana untuk mewujudkan suasana belajar dan proses pembelajaran agar peserta didik secara aktif mengembang potensi dirinya untuk memiliki kekuatan spiritual keagamaan, pengendalian diri, kepribadian, akhlak mulia, serta ketrampilan yang diperlukan dirinya, masyarakat, bangsa dan Negara (Undang-Undang No 20 tahun 2003: 5)

Pendidikan dalam bahasa Arab adalah tarbiyah dengan kata kerja rabb Kata kerja rabba yang artinya mendidik sudah digunakan pada zaman Nabi. Dalam bentuk kata benda, kata rabba ini juga digunakan untuk Tuhan, karena Tuhan juga bersifat mendidik, mengasuh, memelihara (Munjid, 1986: 243). Kata lain yang mengandung arti pendidikan adalah addaba, dan allama (Daradjat, 1992: 25). Sementara Soekanto (1982: 255) mengatakan ada kecenderungan yang kuat bahwa pendidikan yang tinggi merupakan faktor penunjang bagi peningkatan derajat kepatuhan atau kesadaran hukum.

Kepatuhan hukum dan budi pekerti yang baik sangat terkait dengan pendidikan yang diperolehnya, termasuk kepatuhan hukum dan budi pekerti yang dimilki oleh mereka yang terjun di dunia bisnis. Pengetahuan dan pemahaman budi pekerti dan aturan-aturan hukum yang didapat dari dunia pendidikan itu akan diinternalisasikan dalam dirinya sehingga mempengaruhi tingkah laku mereka dalam praktek berdagang mereka. Dalam al-Qur'an, Allah SWT sangat membedakan antara orang yang beilmu dengan orang yang tidak berilmu, sebagaimana tertulis dalam surat AzZumar ayat 9:

"Katakanlah: "Adakah sama orang-orang yang mengetahui dengan orang-orang yang tidak mengetahui?" Sesungguhnya orang yang berakallah yang dapat menerima pelajaran."

Bagi produsen, langkah untuk mewujudkan berbagai kepentingan yang sarat dengan nilai kemanusiaan dan nilai spiritual religius dalam dunia bisnisnya salah satunya adalah dengan 
menjaga produknya agar tetap halal dan memberikan informasi formal kepada konsumen dengan proses sertifikasi dan labelisasi.

\section{Metode Penelitian}

\section{Jenis Penelitian}

Pendekatan yang dipakai dalam penelitian ini adalah pendekatan kuantitatif. Metode penelitian kuantitatif didasarkan oleh filsafat positifme yang memandang realitas dapat diklasifikasikan, relatif tetap, konkrit, teramati, terukur, dan hubungan gejala bersifat sebab akibat (Sugiyono, 2008: 13). Dalam penelitian ini akan digali pengaruh pemahaman agama, motivasi mendapatkan profit dan tingkat pendidikan terhadap kesadaran sertifikasi halal bagi produsen di kabupaten Sleman dan Bantul.

\section{Populai dan Sampel}

Populasi penelitian ini adalah para produsen makanan yang terdapat di Kabupaten Sleman dan Bantul baik yang sudah mensertifikasi produknya dengan sertifikat halal maupun yang belum. Responden pada penelitian ini tidak dibatasi pada para produsen yang beragama Islam karena ada beberapa produsen yang non muslim telah mensertifikasi halal produknya. Jumlah Populasi produsen bersertifikasi halal dan yang tidak bersertifikasi halal dijelaskan dalam tabel 1 berikut ini:

Tabel: 1

\section{Populasi Produsen Makanan}

\begin{tabular}{c|c|c|c}
\hline No & Lokasi & $\begin{array}{c}\text { Populasi Produsen Makanan } \\
\text { Bersertifikasi Halal }\end{array}$ & $\begin{array}{c}\text { Populasi Produsen } \\
\text { Makanan Tidak } \\
\text { Bersertifikasi Halal }\end{array}$ \\
\hline 1 & Sleman & 97 & 60 \\
2 & Bantul & 41 & 14 \\
\multicolumn{2}{|c|}{ Jumlah } & 138 & 74 \\
\hline \multicolumn{2}{l}{ Sumber: LPPOM MUI dan Dinas Perindagkop Kab. Sleman dan Bantul }
\end{tabular}

Sampel pada penelitian ini lebih dari 10 kali jumlah variable, variable yang ada pada penelitian ini sebanyak empat variabel dengan satu variabel dependen dan tiga variabel independen, 
sementara sampel yang ada sejumlah 50 responden dan menurut Sugiono (2008: 125) sudah termasuk layak. Berikut ini ditampilkan tabel proporsi sampel:

Tabel: 2

\section{Jumlah Sampel dan proporsinya}

\begin{tabular}{|c|c|c|c|c|}
\hline No & Produsen & $\begin{array}{l}\text { Jumlah } \\
\text { Populasi }\end{array}$ & $\begin{array}{l}\text { Jumlah } \\
\text { Sampel }\end{array}$ & Proporsi Sampel \\
\hline 1 & $\begin{array}{l}\text { Produsen Makanan } \\
\text { Bersertifikasi Halal }\end{array}$ & 138 & 25 & $18,1 \%$ \\
\hline 2 & $\begin{array}{l}\text { Produsen Makanan } \\
\text { Belum Bersertifikasi } \\
\text { Halal }\end{array}$ & 74 & 25 & $33,8 \%$ \\
\hline & Jumlah & 212 & 50 & $23,6 \%$ \\
\hline
\end{tabular}

Sumber: LPPOM MUI DIY dan Dinas Perindagkop Sleman serta Bantul

\section{Teknik Pengumpulan Data}

Untuk mendapatkan data penelitian, ditempuh dengan beberapa cara, yaitu angket, dukumentasi, dan wawancara. Angket (kuesioner) yang digunakan dalam penelitian ini terdiri dari dua skala, yaitu: Skala Guttman pada variabel dependen Y (kesadaran sertifikasi halal) dan Skala Likert Pada variabel $\mathrm{X}_{1}$ yaitu pemahaman agama dan variabel $\mathrm{X}_{2}$ yaitu motifasi mendapatkan profit. Adapaun variabel $\mathrm{X}_{3}$ (tingkat pendidikan) tidak diukur dengan pertanyaan, akan tetapi dapat diketahui dari kolom identitas responden.

\section{Teknik Analisis Data}

Untuk menguji hipotesis penelitian digunakan analisis regresi berganda, dimana kesadaran untuk sertifikasi halal (Y) merupakan fungsi dari dimensi-dimensi pemahaman agama $\left(\mathrm{X}_{1}\right.$, motivasi mendapatkan profit $\left(\mathrm{X}_{2}\right)$ dan tingkat pendidikan $\left(\mathrm{X}_{3}\right)$ sehingga diperoleh persamaan regresi sebagai berikut:

$$
\mathrm{Y}=\mathrm{a}+\mathrm{b}_{1} \mathrm{X}_{1}+\mathrm{b}_{2} \mathrm{X}_{2}+\mathrm{b}_{3} \mathrm{X}_{3}+\mathrm{e}
$$

Dimana:

a : Konstanta

$\mathrm{X}_{1} \quad$ : Pemahaman Agma

$\mathrm{X}_{2} \quad$ : Motivasi mendapatkan profit 
$\mathrm{X}_{3} \quad$ : Tingkat pendidikan

$\mathrm{b}_{1}-\mathrm{b}_{3}$ : Koefisien Regresi $\mathrm{X}_{1}, \mathrm{X}_{2}, \mathrm{X}_{3}$

e : Kesalahan pengganggu

Sebelum melakukan analisis regresi berganda terlebih dahulu dilakukan uji validitas dan reabilitas serta uji asumsi klasik yang meliputi uji multikolonieritas, autokorelasi, heteroskodastisitas dan uji normalitas.

\section{Analisis Hasil Penelitian}

\section{Uji Validitas}

Uji validitas variabel Y (kesadaran sertifikasi halal) dapat diketahui bahwa semua butir soal untuk kuesioner variabel Y (kesadaran sertifikasi halal) memiliki koefisien korelasi $>$ dari nilai $r$ kritis 0,300, dengan demikian item pertanyaan tersebut dinyatakan valid, yang berarti soal tersebut baik untuk dijadikan instrument. Uji validitas variabel $\mathrm{X}_{1}$ (Pemahaman agama) dan $\mathrm{X}_{2}$ (motivasi mendapatkan profit) juga memiliki koefisien korelasi $>$ dari nilai $r$ kritis 0,300, dengan demikian semua item pertanyaan pada variable $\mathrm{X}_{1}$ (Pemahaman agama) dan $\mathrm{X}_{2}$ (motivasi mendapatkan profit) tersebut dinyatakan valid, yang berarti soal tersebut baik untuk dijadikan instrumen.

\section{Uji Reabilitas}

Tabel: 3

\section{Ringkasan Hasil Uji Reliabilitas Variabel $Y, \mathbf{X}_{1}$ dan $\mathbf{X}_{2}$ (nilai r kritis $=0,300$ )}

\begin{tabular}{|c|c|c|c|}
\hline No & Variabel & Cronbach's Alpha & Keterangan \\
\hline 1 & $\mathrm{Y}$ & 0,919 & Reliabel \\
2 & $\mathrm{X}_{1}$ & 0,924 & Reliabel \\
3 & $\mathrm{X}_{2}$ & 0,830 & Reliabel \\
\hline
\end{tabular}

Sumber: Lampiran hasil SPSS diolah kembali 
Pada tabel 3 di atas dapat kita ketahui bahwa nilai koefisien alpha cronbach untuk semua variabel di atas (Y, X1 dan X2) masingmasing > dari pada nilai $\mathrm{r}$ kritis 0,300, maka dapat disimpulkan bahwa kuesioner pada setiap variabel tersebut bersifat reliabel. Dengan kata lain semua butir pertanyaan dalam kuesioner mengenai variabel kesadaran sertifikasi halal, pemahaman agama dan motifasi mendapatkan profit merupakan instrumen yang dapat dipercaya.

\section{Uji Asumsi Klasik}

Uji Normalitas

Uji statistik yang dipakai dalam penelitian ini adalah uji Kolmogorov-Smirnov Test dan analisis grafik (normal P-P plot). Hasil uji normalitas dapat dilihat pada tabel 4 berikut ini:

Tabel: 4

Ringkasan Hasil Uji Normalitas Dengan

\begin{tabular}{|c|c|c|c|}
\hline No & Variabel & Asymp. Sig & Keterangan \\
\hline 1 & $\mathrm{X}_{1}$ & 0,361 & Normal \\
$\mathbf{2}$ & $\mathrm{X}_{2}$ & 0,234 & Normal \\
$\mathbf{3}$ & $\mathrm{X}_{3}$ & 0,086 & Normal \\
\hline
\end{tabular}

Sumber: Lampiran hasil SPSS diolah kembali

Dari tabel 4 hasil uji K-S di atas, dapat diketahui bahwa variabel $\mathrm{X} 1$ (pemahaman agama) nilai probabilitasnya $0,361>0,05$, variabel $\mathrm{X} 2$ (motivasi mendapatkan profit) nilai probabilitasnya $0,234>0,05$ dan variabel X3 (tingkat pendidikan) nilai probabilitasnya 0,086 > 0,05 . Kesemua variabel independen tersebut mempunyai nilai Asymp. Sig (2-tailed) $>0,05$, artinya data residual berdistribusi normal.

Uji Multikolinieritas

Multikolinieritas berarti terjadi situasi dimana dua atau lebih variabel penjelas atau independen bisa sangat berhubungan linier. Untuk mendeteksi multikolinieritas dalam penelitian ini, penulis menggunakan nilai tolerance dan inflantion factor (VIF) pada model regresi. Adapun hasil uji multikoliniieritas dapat dilihat pada tabel 5 berikut ini: 
Tabel: 5

Ringkasan Hasil Uji Multikolinearitas

\begin{tabular}{|cc|c|c|c|c|}
\hline No & Variabel & Toleransi & VIF & Kondisi & Kesimpulan \\
\hline 1 & $\mathrm{X}_{1}$ & 0,802 & 1,246 & $\begin{array}{c}0,802 \text { mendekati } 1 \\
\& 1.246<10\end{array}$ & Tidak terjadi \\
\hline 2 & $\mathrm{X}_{2}$ & 0,790 & 1,267 & $\begin{array}{c}0,790 \text { mendekati } 1 \\
\& 1.267<10\end{array}$ & Multikoliniearitas \\
\hline 3 & $\mathrm{X}_{3}$ & 0,970 & 1,031 & $\begin{array}{c}0,970 \text { mendekati } 1 \\
\& 1.031<10\end{array}$ & \\
\hline
\end{tabular}

Sumber: Lampiran hasil SPSS diolah kembali

Berdasarkan Tabel 5 dapat dilihat semua variabel $\left(\mathrm{X}_{1}, \mathrm{X}_{2}\right.$ dan $\mathrm{X}_{3}$ ) nilai VIF-nya $<10$ dan nilai toleransinya mendekati 1 , dengan demikian tidak terjadi multikolinieritas.

Uji Heteroskedastisitas

Pengujian gejala heteroskedastisitas dilakukan untuk mengetahui ada tidaknya hubungan antara variabel pengganggu atau residual (sisa) dengan variabel bebasnya. Pengujian gejala heteroskedastisitas pada penelitian ini menggunakan uji koefisien korelasi spearmen's rho. Hasil uji heteroskedastisitas dengan uji koefisien korelasi spearmen's rho dapat dilihat pada tabel berikut ini:

Tabel: 6

Ringkasan Hasil Uji Heteroskedastisitas

\begin{tabular}{|cc|c|c|c|}
\hline $\begin{array}{c}\text { No Unstandardized } \\
\text { Residual }\end{array}$ & $\begin{array}{c}\text { Sig. } \\
(\text {-tailed })\end{array}$ & Kondisi & Keterangan \\
\hline 1 & $\mathrm{X}_{1}$ & 0,386 & $0,386>0,05$ & Tidak \\
\hline 2 & $\mathrm{X}_{2}$ & 0,454 & $0,454>0,05$ & Terjadi \\
\hline 3 & $\mathrm{X}_{3}$ & 0,499 & $0,499>0,05$ & Heteroskedastisitas \\
\hline
\end{tabular}

Sumber: Lampiran hasil SPSS diolah kembali

Dari tabel 6, dapat diketahui bahwa uji koefisien korelasi spearmen's rho, yaitu korelasi masing-masing variable independen dengan residualnya memiliki signifikansi $>0,05$. Karena korelasi antar variable independen dengan residual memberikan signifikansi lebih dari 0,05 maka dapat dikatakan bahwa tidak terjadi problem heteroskedastisitas. 


\section{Autokorelasi}

Pengujian autokorelasi pada hasil penelitian ini menggunakan uji Durbin Watson (DW). Nilai Dublin Watson hasil perhitungan statistik dapat dilihat melalui tabel Model Summary pada tabel 7 berikut ini:

Tabel: 7

\section{Uji Autokorelasi}

\begin{tabular}{|c|c|c|c|c|c|}
\hline Model & $\mathrm{R}$ & $\begin{array}{c}\mathrm{R} \\
\text { Square }\end{array}$ & $\begin{array}{c}\text { Adjusted R } \\
\text { Square }\end{array}$ & $\begin{array}{c}\text { Std. Error of } \\
\text { the Estimate }\end{array}$ & $\begin{array}{c}\text { Durbin- } \\
\text { Watson }\end{array}$ \\
\hline 1 & $.817^{\mathrm{a}}$ & .667 & .645 & 1.975 & 1.665 \\
\hline & & & & & \\
\hline
\end{tabular}

Sumber: Lampiran hasil SPSS diolah kembali

Tabel 7 menujukkan nilai Durbin-Watson sebesar 1.665 yaitu berkisar antara 1,55 sampai 2,46 dalam artian mendekati 2. Pada df

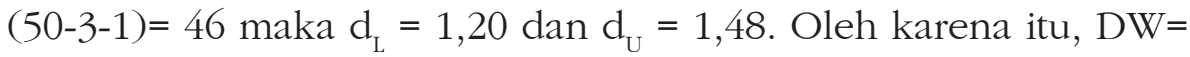
$1,665>\mathrm{d}_{\mathrm{U}}=1,48$, dengan demikian tidak terjadi autokorelasi pada model regresi.

\section{Hasil Estimasi Persamaan Regresi Berganda}

Untuk melihat hasil estimasi persamaan regresi pengaruh dimensi-dimensi pemahaman agama, motivasi mendapatkan profit dan tingkat pendidikan terhadap kesadaran sertifikasi halal, dapat kita peroleh dengan melihat koefisien masing-masing variabel dari ringkasan hasil perhitungan statistik pada tabel berikut ini:

Tabel: 8

\section{Ringkasan Hasil Estimasi Regresi}

\begin{tabular}{|c|l|c|c|c|c|}
\hline No & Variabel & Koefisien & Std.Error & t-hitung & Sig. \\
\hline 1 & Konstanta C & $-32,179$ & 4,523 & $-7,114$ & 0,000 \\
2 & $\begin{array}{l}\text { Pemahaman } \\
\text { agama }\end{array}$ & 0,694 & 0,102 & 6,815 & 0,000 \\
& $\begin{array}{l}\text { Motivasi } \\
4\end{array}$ & 0,349 & 0,135 & 2,586 & 0,013 \\
& $\begin{array}{l}\text { Mendapat profit } \\
\text { Ttingkat }\end{array}$ & 0,373 & 0,254 & 1,471 & 0,148 \\
\hline
\end{tabular}




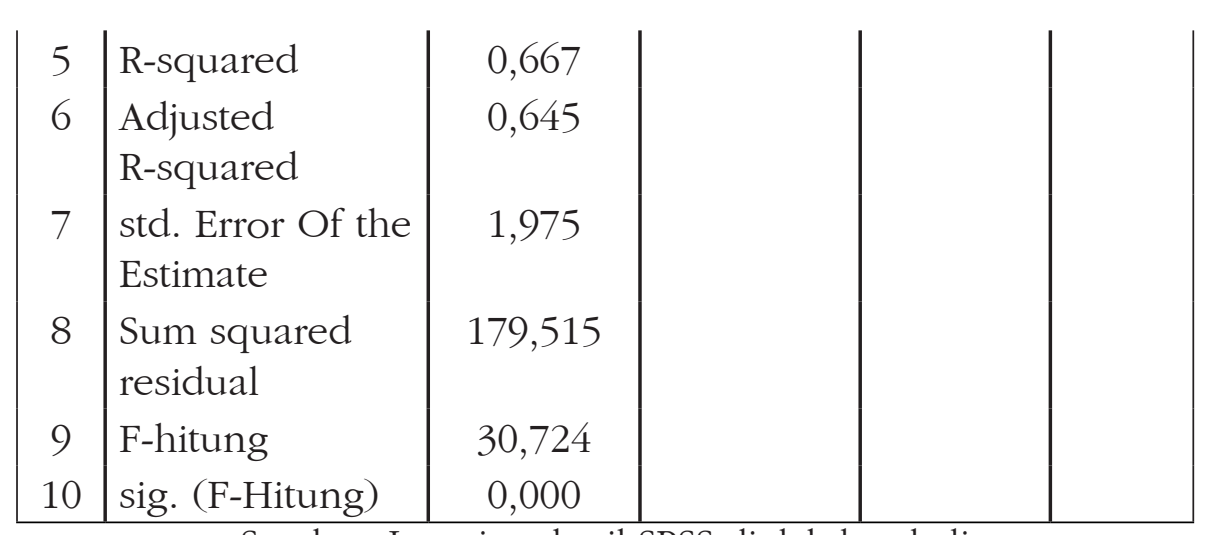

Sumber: Lampiran hasil SPSS diolah kembali

Berdasarkan hasil ringkasan estimasi regresi di atas, maka persamaan regresi linear berganda yang didapat adalah sebagai berikut:

$$
\mathrm{Y}=-32,179+0,694 \mathrm{X}_{1}+0,349 \mathrm{X}_{2}+0,373 \mathrm{X}_{3}
$$

Kesadaran sertifikasi halal $=-32,179+0,694$ Pemahaman agama $+0,349$ Motivasi mendapatkan profit $+0,373$ Tingkat Pendidikan

Persamaan regresi linear berganda pada table 8 di atas dapat diinterpretasikan sebagai berikut:

a. Nilai-32,179 adalah harga koefisien konstanta, yaitu besarnya skor variabel $\mathrm{Y}$ (kesadaran sertifikasi halal) yang tidak dipengaruhi oleh variabel-variabel independen $\mathrm{X}_{1}$ (pemahaman agama), $\mathrm{X}_{2}$ (motivasi mendapatkan profit) dan $\mathrm{X}_{3}$ (tingkat Pendidikan). Hal ini berarti bahwa, apabila nilai dari $\mathrm{X}_{1}$ (pemahaman agama), $\mathrm{X}_{2}$ (motivasi mendapatkan profit) dan $\mathrm{X}_{3}$ (tingkat Pendidikan) $\mathrm{di}$ obyek penelitian sama dengan nol, maka tingkat atau besarnya variabel dependen Y (kesadaran sertifikasi halal) di lokasi tersebut akan sebesar -32,179 persen.

b. Harga koefisien $b_{1}=0,694$, berarti bahwa, apabila nilai $\mathrm{X}_{1}$ (pemahaman agama) mengalami kenaikan sebesar satu poin, sementara variabel independen lainnya bersifat tetap, maka tingkat variabel Y (kesadaran sertifikasi halal) di obyek penelitian akan meningkat sebesar 0,694 persen.

c. Harga koefisien $b_{2}=0,349$, berarti bahwa, apabila nilai $\mathrm{X}_{2}$ (motivasi 
mendapatkan profit) mengalami kenaikan sebesar satu poin, sementara variabel independen lainnya bersifat tetap, maka tingkat variabel Y (kesadaran sertifikasi halal) di obyek penelitian akan meningkat sebesar 0,349 persen.

d. Harga koefisien $b_{3}=0,373$, berarti bahwa, apabila nilai $\mathrm{X}_{3}$ (tingkat pendidikan) mengalami kenaikan sebesar satu poin, sementara variabel independen lainnya bersifat tetap, maka tingkat variabel $Y$ (tingkat pendidikan) di obyek penelitian akan meningkat sebesar 0,373 persen.

Sesuai dengan persamaan garis regresi di atas, maka perubahan tingkat variabel $\mathrm{Y}$ (kesadaran sertifikasi halal) yang terjadi di obyek penelitian akan searah dengan perubahan yang terjadi pada $\mathrm{X}_{1}$ (pemahaman agama), $\mathrm{X}_{2}$ (motivasi mendapatkan profit) dan $\mathrm{X}_{3}$ (tingkat Pendidikan) di obyek penelitian, hal ini dikarenakan koefisien regresi pada variabel independennya seluruhnya bertanda positif. Oleh karena itu penurunan nilai pada variabel independen akan mengakibatkan pada tingkat variabel $Y$, demikian juga peningkatan nilai pada variabel independen $\mathrm{X}_{1}$ sampai $\mathrm{X}_{3}$ akan mengakibatkan peningkatan pada variabel dependen.

\section{Signifikansi Hasil Estimasi}

Uji F (Uji Signifikansi Simultan)

Uji signifikansi simultan dilakukan dengan uji F. Uji F digunakan untuk menguji variabel independen secara keseluruhan dan bersama-sama, untuk melihat apakah variabel independen secara bersama-sama mempengaruhi mempengaruhi variabel dependen secara signifikan. Adapun formulasi hipotesis adalah sebagai berikut:

Ho: Tidak ada pengaruh secara bersama antara variabel $\mathrm{X}_{1}, \mathrm{X}_{2}$ dan $\mathrm{X}_{3}$ terhadap nariabel $\mathrm{Y}$

Ha: Ada pengaruh secara bersama antara variabel $\mathrm{X}_{1}, \mathrm{X}_{2}$ dan $\mathrm{X}_{3}$ terhadap nariabel Y

Dalam uji $\mathrm{F}$ ini digunakan taraf keyakinan 95\% atau $\square=0,05$ dan df1= $\mathrm{k}-1=4-1=3$ dan df $2=\mathrm{n}-\mathrm{k}=50-4=46$ diperoleh nilai $\mathrm{F}$-tabel 2,81. Kriteria pengujian nilai $\mathrm{F}$ adalah jika F-hitung $>$ F-tabel maka 
Ho ditolak dan Ha diterima yang berarti bahwa ada pengaruh secara serempak atau bersama-sama dari keseluruhan variabel independen terhadap variabel dependen. Sebaliknya jika F-hitung < F-tabel maka H0 diterima dan Ha ditolak, yang berarti bahwa tidak ada pengaruh secara serempak dari keseluruhan variabel independen terhadap variabel dependen. Berdasarkan hasil pada tabel 8 di atas diketahui $\mathrm{F}$ hitung atau $\mathrm{F}$ statistik sebesar 30,724, sedangkan nilai F-tabel 2,81. Berdasarkan data ini, diketahui bahwa F hitung $>$ F tabel sehingga Ho ditolak dan Ha diterima, artinya secara simultan pemahaman agama (X1), motifasi mendapatkan profit(X2) serta tingkat pendidikan(X3) berpengaruh terhadap variabel dependen Y (kesadaran sertifikasi halal).

\section{Uji t (Uji Signifikansi Parsial)}

Uji signifikansi parsial dilakukan dengan menggunakan uji t. Uji parsial atau uji $\mathrm{t}$ ini digunakan untuk mengetahui apakah masing-masing variabel $\mathrm{X}$ secara individu berpengaruh terhadap variable $Y$. Karena dalam penelitian ini ada tiga variabel independen maka formulasi hipotesisnya adalah sebagai berikut:

Ho: Tidak ada pengaruh variabel $\mathrm{X}_{1}$ terhadap variabel $\mathrm{Y}$ secara signifikan apabila variabel $\mathrm{X}_{2}$ dan $\mathrm{X}_{3}$ dikendalikan (ceteris paribus)

Ho: Tidak ada pengaruh variabel $\mathrm{X}_{2}$ terhadap variabel $\mathrm{Y}$ secara signifikan apabila variabel $\mathrm{X}_{1}$ dan $\mathrm{X}_{3}$ dikendalikan (ceteris paribus)

Ho: Tidak ada pengaruh variabel $\mathrm{X}_{3}$ terhadap variabel $\mathrm{Y}$ secara signifikan apabila variabel $\mathrm{X}_{1}$ dan $\mathrm{X}_{2}$ dikendalikan (ceteris paribus)

Ha: Terdapat pengaruh variabel $\mathrm{X}_{1}$ terhadap variabel $\mathrm{Y}$ secara signifikan apabila variabel $\mathrm{X}_{2}$ dan $\mathrm{X}_{3}$ dikendalikan (ceteris paribus)

Ha: Terdapat pengaruh variabel $\mathrm{X}_{2}$ terhadap variabel $\mathrm{Y}$ secara signifikan apabila variabel $\mathrm{X}_{1}$ dan $\mathrm{X}_{3}$ dikendalikan (ceteris paribus)

Ha: Terdapat pengaruh variabel $\mathrm{X}_{3}$ terhadap variabel $\mathrm{Y}$ secara signifikan apabila variabel $\mathrm{X}_{1}$ dan $\mathrm{X}_{2}$ dikendalikan (ceteris paribus)

Dalam uji t ini digunakan taraf keyakinan 95\% atau $\alpha=0,05$ dan $\mathrm{df}=\mathrm{n}-\mathrm{k}=50-4=46$ diperoleh nilai t-tabel 1,68. Kriteria pengujian nilai $\mathrm{t}$ adalah Ho ditolak dan $\mathrm{Ha}$ diterima apabila $\mathrm{t}_{\text {hitung }}>\mathrm{t}_{\text {tabel }}$ dan Ho diterima dan Ha ditolak apabila $\mathrm{t}_{\text {hitung }}<\mathrm{t}_{\text {tabel }}$ 
dan juga digunakan perbandingan antara signifikansi t hitung dengan alpha $\alpha=0,05$, dengan ketentuan Ho ditolak dan Ha diterima apabila signifikansi t hitung < alpha serta menerima ho dan menolak Ha apabila signifikansi thitung > alpha. Berdasarkan tabel 8 tentang ringkasan hasil estimasi regresi dan hasil $t_{\text {tabel }}$, maka uji signifikansi parsial dapat disajikan dalam tabel berikut ini:

Tabel: 9

\section{Ringkasan Hasil Uji t}

\begin{tabular}{|c|c|c|c|c|c|}
\hline Variabel Independen & Sign & $(\alpha)$ & t-hitung & t-tabel & Keterangan \\
\hline $\begin{array}{c}\text { X1 } \\
\text { (pemahaman agama) }\end{array}$ & 0,000 & 0,05 & 6,815 & 1,68 & Signifikan \\
$\begin{array}{c}\text { X2 } \\
\text { (motivasi } \\
\text { mendapatkan profit) } \\
\begin{array}{c}\text { X }_{3} \\
\text { (tingkat pendidikan) }\end{array}\end{array}$ & 0,013 & 0,05 & 2,586 & 1,68 & Signifikan \\
\hline
\end{tabular}

Sumber: Lampiran hasil SPSS diolah kembali

Berdasarkan tabel 9 di atas maka dapat dilakukan pengujian hipotesis untuk setiap variabel independen sebagai berikut:

1. Pengujian Hipotesis Pertama

Berdasarkan hasil analisis regresi linear berganda yang disajikan dalam tabel 9 diperoleh bahwa besarnya $t_{\text {hitung }}$ untuk variabel pemahaman agama $\left(\mathrm{X}_{1}\right)$ sebesar 6,815 dengan $\mathrm{t}_{\text {tabel }}=1,68$ maka nilai $t_{\text {bitung }}>t_{\text {tabel }}$. Sementara nilai signifikansi $\mathrm{t}_{\text {hitung }}$ variabel pemahaman agama $\left(\mathrm{X}_{1}\right)$ sebesar 0,000 , maka nilai signifikansi $\mathrm{t}_{\text {hitung }}<\square(0.05)$. Berdasarkan hasil tersebut maka Ho ditolak dan Ha diterima yang berarti bahwa pemahaman agama $\left(\mathrm{X}_{1}\right)$ berpengaruh secara signifikan terhadap kesadaran sertifikasi halal (Y) dan diasumsikan variabel motivasi mendapatkan profit $\left(\mathrm{X}_{2}\right)$ dan tingkat pendidikan $\left(\mathrm{X}_{3}\right)$ dikendalikan (ceteris paribus).

2. Pengujian Hipotesis Kedua

Berdasarkan hasil analisis regresi linear berganda yang disajikan dalam tabel 4.6 diperoleh bahwa besarnya $t_{\text {hitung }}$ untuk variabel 
motivasi mendapatkan profit $\left(\mathrm{X}_{2}\right)$ sebesar 2,586 dengan $\mathrm{t}_{\text {tabel }}$ $=1,68$ maka nilai $t_{\text {bitung }}>t_{\text {tabel }}$. Sementara nilai signifikansi $\mathrm{t}_{\text {hitung }}$ motivasi mendapatkan profit $\left(\mathrm{X}_{2}\right)$ sebesar 0,013 , maka nilai signifikansi $\mathrm{t}_{\text {hitung }}<\square(0.05)$. Berdasarkan hasil tersebut maka Ho ditolak dan Ha diterima yang berarti bahwa motivasi mendapatkan profit $\left(\mathrm{X}_{2}\right)$ berpengaruh secara signifikan terhadap kesadaran sertifikasi halal (Y) dan diasumsikan variabel pemahaman agama $\left(\mathrm{X}_{1}\right)$ dan tingkat pendidikan $\left(\mathrm{X}_{3}\right)$ dikendalikan (ceteris paribus).

\section{Pengujian Hipotesis Ketiga}

Berdasarkan hasil analisis regresi linear berganda yang disajikan dalam tabel 9 diperoleh bahwa besarnya $\mathrm{t}_{\text {hitung }}$ untuk variabel tingkat pendidikan $\left(\mathrm{X}_{3}\right)$ sebesar 1,471 dengan $\mathrm{t}_{\text {tabel }}=1,68$ maka nilai $t_{\text {bitung }}<t_{\text {tabel }}$. Sementara nilai signifikansi $t_{\text {hitung }}$ tingkat pendidikan $\left(\mathrm{X}_{3}\right)$ sebesar 0,148 , maka nilai signifikansi $\mathrm{t}_{\text {hitung }}$ $>\square(0.05)$. Berdasarkan hasil tersebut maka Ho diterima dan Ha ditolak yang berarti bahwa tingkat pendidikan $\left(\mathrm{X}_{3}\right)$ tidak berpengaruh secara signifikan terhadap kesadaran sertifikasi halal $(\mathrm{Y})$ dan diasumsikan variabel pemahaman agama $\left(\mathrm{X}_{1}\right)$ dan motivasi mendapatkan profit $\left(\mathrm{X}_{2}\right)$ dikendalikan (ceteris paribus).

\section{Pemeriksaan Koefisien Determinasi $\left(R^{2}\right)$}

Pengujian ini dilakukan untuk mengetahui seberapa besar sumbangan variabel indevenden pemahaman agama $\left(\mathrm{X}_{1}\right)$, motivasi mendapatkan profit $\left(\mathrm{X}_{2}\right)$ dan tingkat pendidikan $\left(\mathrm{X}_{3}\right)$ terhadap variabel kesadaran sertifikasi halal (Y). Besarnya nilai $\mathrm{R}^{2}$ diantara nol dan satu $\left(0<\mathrm{R}^{2}<1\right)$, dengan ketentuan sebagai berikut:

Berdasarkan tabel 8 nilai $\mathrm{R}^{2}$ sebesar 0,667 atau semakin mendekati angka 1 yang berarti hubungan antara variabel bebas dengan variabel terikat semakin erat dan dekat maka model tersebut dapat nilai baik dan hal itu juga menunjukkan bahwa ketiga variabel bebas berpengaruh sebesar $66,7 \%$ terhadap variabel terikat, sisanya dipengaruhi oleh faktor lain sebesar 34,3\%. Dengan kata lain, hal ini berarti besarnya sumbangan variabel indevenden pemahaman agama $\left(\mathrm{X}_{1}\right)$, motivasi mendapatkan profit 
$\left(\mathrm{X}_{2}\right)$ dan tingkat pendidikan $\left(\mathrm{X}_{3}\right)$ terhadap variabel kesadaran sertifikasi halal (Y) adalah sebesar 66,7\%. Adapun nilai Adjusted $\mathrm{R}^{2}$ pada tabel 8 sebesar 0,645 , ini juga tidak jauh dari nilai koefisien determinasi $\left(\mathrm{R}^{2}\right)$ yang mendekati angka 1 sehingga model ini dapat nilai baik.

\section{Kesimpulan}

Berdasarkan tujuan penelitian dan data yang diolah dapat kita peroleh kesimpulan sebagai berikut:

Secara simultan variabel independen $(\mathrm{X} 1=$ pemahaman agama, $\mathrm{X} 2=$ motifasi mendapatkan profit dan $\mathrm{X} 3=$ tingkat pendidikan) berpengaruh secara signifikan dalam mempengaruhi variabel dependen $\mathrm{Y}=$ kesadaran sertifikasi halal para produsen makanan di kabupaten Sleman dan Bantul. Hal ini terlihat pada uji $\mathrm{F}$ dengan bantuan program SPSS 17 yang menghasilkan $\mathrm{F}$ hitung atau F statistik lebih besar dari nilai F-tabel.

Berdasarkan hasil uji t diketahui bahwa variabel - variabel independen (pemahaman agama, motivasi mendapatkan profit dan tingkat pendidikan) yang berpengaruh secara signifikan ada dua variabel, yaitu pemahaman agama dan motivasi mendapatkan profit, sementara tingkat pendidikan para responden tidak mempunyai pengaruh yang signifikan terhadap kesadaran sertifikasi halal di kabupaten Sleman dan Bantul.

Nilai $R^{2}$ sebesar 0,667 yang berarti hubungan antara variabel bebas dengan variabel terikat semakin erat dan dekat maka model tersebut dapat nilai baik dan hal itu juga menunjukkan bahwa ketiga variabel bebas berpengaruh sebesar 66,7\% terhadap variabel terikat, sisanya dipengaruhi oleh faktor lain sebesar 34,3\%.

\section{Daftar Pustaka}

Abdul, Mohani, Hasanah, Ismail, Hashim, Haslina, dan Johari, Juliana. 2009. Consumer Decision Making Prosess in Shopping for Halal Food in Malaysia, USA: China-USA Business Revies. Abdul Wahab, Muhammad. 1997. Kitab Utsulu Atsalatsah, Riyad: Dar Ats-Tsurya. 
Aitelmaelem, Hicham, Breland, Patti, dan Zayak, Leona Reynolds. 2005. Canadian Halal Meat Market Study: an Alternative Market For Alberta's Meat Industry, Canada: Alberta.

Al-Hafid, Ibnu Rusd, Tth. Bidayatul Mujtahid Wa Nihayatul Muqtashid, Ttp: Darr al-Kutub Al-Islamiyah.

Alma, Buchari. 2009. Pengantar Bisnis, Bandung: CV. Alfabeta. Al-Utsaimin. 2003. Syarbu al-Ushul al-Fiqh, Kairo: Dar Ibn alHaitsami.

Al-Utsaimin. 1997. Syarhu Tsalatsati al-Ushul, Riyad: Dar al-Tsurya. An-Najar, Abdul Jabar, Muslih. 2002. al-Adillah al-Mukbtalaf Fiha 'inda al-Ushuliyyin wa thathbiqatiha al-Mu'ashirah, Riyad: Maktabah ar-Rusyd.

Apriyantono, Anton dan Nurbowo. 2003. Panduan Belanja dan Konsumsi Halal. Jakarta: Khairul Bayan.

Apriyantono, Anton. 2007. Pengetahuan Baban Haram dan Syubhat, Jakarta: Khairul Bayan Press.

As-Sa'di, Ibnu Nashir, Abdurrahman. 2005. Taisirul Karimir Rabman Fi Tafsiri Kalamil Manan, Riyad: Dar Assunah.

Asy Syatibi, Abu Ishaq. T.th. al Muwafaqat fi Ushul al Syari'at. Dar al Kitab al-'Ilmiyat: Bairut Libanon.

Asy-Syaukani. 2001. Fathul Qadir, Riyad: Maktabah Ar-Rusyd.

Azwar, S. 1996. Tes Prestasi. Yogyakarta: Pustaka Pelajar Badan Pusat Statistik 2000

Badan Pusat Statistik Kabupaten Bantul, 2008.

Badan Pusat Statistik Kabupaten Sleman, 2008.

Chapra, Umer. 2001. The Future of Economiccs An Islamic Perspective, Jakarta: SEBI.

Daradjat, Zakiah. 1992. Ilmu Pendidikan Islam, Jakarta : Bumi Aksara.

Husaini, Andian. 2005. Wajah Peradaban Barat. Jakarta: Gema Insani..

Jurnal Halal LPPOM MUI, No. 79, Edisi Sepetember - Oktober, Tahun XII 2009.

Kotler, Philip. 1989. Manajemen Pemasaran, Jakarta: Erlangga

Muhammad dan AS Pelu, Elmi, Ibnu. 2009. Label Halal Antara 
spiritual Bisnis dan Komoditas Agama, Malang: Madani.

Muhammad, Nik Maheran Nik, Isa, Filzah Md., Kifli, Bidin, Chee. 2009. "Positioning Malaysia as Halal-Hub: Integration Role of Suply Chain Strategy and Halal Assurance System",: Journal Asian Social Science Vol. 5, No. 7.

Pedoman Fawa Produk Halal MUI. 2003. Jakarta: Proyek Pembinaan Pangan Halal ditjen Bimas Islam dan Penyelenggaraan Haji DEPAG RI.

Porwadarminta, W.J.S. 1991. Kamus Besar Bahasa Indonesia, Jakarta : Balai Pustaka.

Purwanto, Yadi. 2007. Psikologi Kepribadian Integritas Nafsiyah dan 'Aqliyah Perspektif Psikologi Islami, Bandung: PT Refika Aditama

Qardhawi, Yusuf. 1995. Peran Nilai dan Moral dalam Perekonomian Islam. Terj. Didin Hafifuddin. Jakarta: Robbani Press.

Sabiq, Sayyid. 1999. Fiqh As Sunnah. Kairo: Dar El Fath.

Sakr, Ahmad. 1996. Understanding Halal Foods Fallacies and Facts.

Lombart Illionis: Foundation For Islamic Knowledge.

Sugiyono. 2008. Metode Penelitian Bisnis, Bandung: Alfabeta.

Soekanto, Soerjono. 1982. Sosiologi Hukum Dalam Masyarakat, Jakarta: Rajawali press.

Stiglitz, Josep E. 2006. Dekade Keserakahan Era '90-an dan Awal Mula Petaka Ekonomi Dunia. Terj. Jakarta: Marjin Kiri.

Sudjana. 1996. Metode Statistika, Bandung: Tarsito..

Undang-Undang No 20 tahun 2003 pasal 1 ayat (1)

Widjaja, SW. 1980. Kesadaran Hukum Manusia dan Masyarakat Pancasila, Jakarta: CV. Era Swara.

www.almoslim.net. 